\title{
Implementation of Scouting Education Compulsory Extracurricular Activities at Sekolah Dasar Negeri 02 and 04 BPR Ranau Tengah
}

\author{
Hamidah $^{1 *}$, Yasir Arafat ${ }^{2}$, Yenny Puspita ${ }^{2}$ \\ ${ }^{1}$ SD Negeri 04 Buay Pematang Ribu Ranau Tengah OKU Selatan Regency, South of Sumatra, Indonesia \\ ${ }^{2}$ University of PGRI, Palembang, Indonesia \\ *Corresponding author. Email: hamidahmuis11@gmail.com
}

\begin{abstract}
The goal of the compulsory scouting of extracurricular education events is to ensure that students have a good moral and social character, a strong Indonesian nationality and state, and a strong capacity to survive in the midst of society. In addition, Scouting Compulsory extracurricular activities are now being carried out to improve character education for students. The attainment of the basic competencies and core competencies alluded to in the 2013 Program will be accomplished by the incorporation of intra-curricular, co-curricular and extra-curricular activities. Through extracurricular experiences, students can explore and grow their potential, as well as have great social advantages through improving their capacity to interact and collaborate with others. This research uses a descriptive qualitative approach. The results showed that the compulsory scouting of extracurricular sports in the schools under review was not maximal. The solution is that school principals, teachers, scouts and other support personnel must have the same perception and dedication to enhancing results.
\end{abstract}

Keywords: Compulsory Extracurricular Activities, Scouting, Curriculum, Character Education

\section{INTRODUCTION}

Appertaining to Law No. 12 of 2010 on the Scouting Movement Article 15 specifies that the Scouting Education Program contains elements of the principles found in Dasa Darma Pramuka and comprises of general skills and special skills structured in compliance with the Scouting Education Level and must conform with the specifications of the curriculum standards set by the standardization body in accordance with Article 15 . People who believe in, are active, imaginative, inventive and affective, and are capable of contributing to the life of society, country, state and global civilization [1].

In order to improve the awareness of the curriculum, the Ministry of Education and Culture of the Republic of Indonesia released Regulation No 63 of 2014 on Scouting Education as an Extra-curricular Compulsory, which also specifies the curriculum as set out in the above statement. It can therefore be inferred that the purpose of the 2013 curriculum is to build and enhance human capital as a model for the growth of the nation and state of Indonesia, as well as to increase healthy competitiveness between education units on the standard of education to be achieved.
According to Mulyasa [2] several roles of teachers as educators include: a) a teacher as a facilitator; b) a teacher as a motivator; c) a teacher as a learning driver; and d) a teacher as an encouragement. From the above view, it can be inferred that the instructor must always know and realize that the actual success of the teacher is very noble. For this purpose, teachers ought to practice in line with their standards, so that they can increase the standard of education and deliver quality for future generations. Qualified teachers can also produce quality students [3].

Scouting compulsory extracurricular education aims to make students have a strong moral and social character, strong Indonesian nationality and state, and strong self-skills to allow students to live in the midst of society. In addition, Scouting Compulsory extracurricular exercises are now being carried out to improve character formation for students. The attainment of the basic competencies and core competencies alluded to in the 2013 Program will be accomplished by the incorporation of intra-curricular, co-curricular and extracurricular activities. Through extracurricular experiences, students can explore and grow their potential, as well as have great social advantages through improving their capacity to interact and collaborate with others. 
In 2014, the Ministry of Education and Culture of the Republic of Indonesia released Regulation (Permendikbud) No 63 on Scouting Education as an Extracurricular Compulsory for Primary and Secondary Education. The goal of the Minister of Education and Culture is to find out that Scouting Education is a vehicle for the psychological-socio-cultural reinforcement (reinforcing) of attitudes and skills in the 2013 curriculum that is psychopedagogically compatible (linking) with the production of scouting attitudes and skills. Through extracurricular experiences, students can explore and grow their potential, as well as have great social advantages through improving their capacity to interact and collaborate with others. The achievement of the Key Competitions for Moral Attitudes (KI-1), Social Attitudes (KI-2) and Skills (KI-4) thus provides practical learning through the system-adaptive facilitation of scouting instruction in educational units.

However, since its inception in 2014, Scouting Compulsory Extracurricular Sports in Elementary and Middle Schools have faced numerous difficulties in their execution. This is usually induced by the misperception of education unit managers in interpreting the contents of Permendikbud No. 63 of 2014 on Scouting Education as an Extracurricular Compulsory in Primary and Secondary Education [4].

As for the misperception that is intended among other things: first, there is a misunderstanding that if the school has adopted one of the activity models between block, upgrade and normal, it is assumed to have introduced the Mandatory Scouting Education Compulsory Extracurricular. The fact is, schools are applying all three versions. Second, the presumption is false if the scout coach was the technical person in charge of carrying out compulsory extracurricular tasks both in blocks, upgrading and on a daily basis in schools, so that the class leader leaves it entirely to the respective supervisor.

On the basis of this context, the introduction of the Compulsory Scouting Education Compulsory Excursion often pays attention to issues that are proclaimed to the goal of character development values to crystallize the five values of strengthening character education, namely faith, dignity, nationalism, freedom and mutual participation, as well as the promotion of trends or models. The authors therefore undertook research to assess the scope of the attempts made by educational organizations to introduce scouting education as a compulsory extracurricular sport in schools as an educational entity.

This research is intended to be useful: (1) Theoretical benefits; add perspective and information to researchers involved in conducting research on the application of compulsory extracurricular scouting programs in schools; (2) Tangible benefits; (a) for schools, they will make a positive contribution to school development and provide insight into successful teaching and learning management, in particular through the introduction of compulsory extracurricular scouting; (b) for students, learn by experience using a tool to enhance learning outcomes, to think objectively and reduce students' boredom, and to develop principles of character education and national character, and (c) For principals and lecturers/teachers in the field of research and scout coaches, the findings of this study can be a learning technique that can be implemented to enhance student learning outcomes and to better incorporate scouting practices as compulsory extracurricular activities in schools. The Principal, through his style of leadership, must be able to control other individuals or subordinates [5]. The principal as the leader of the educational institution functions as the person in charge of all educational activities in the school [6].

\section{METHODS}

This analysis uses a descriptive method of testing with a qualitative approach. Sukmadinata [7] states that qualitative analysis is a study aimed at identifying and evaluating behaviors, incidents of social life, behavior, views, expectations, thoughts of individuals or communities. The choice of a qualitative approach in this research was based on the explanation that the issue discussed in this study was how to introduce compulsory out-of-school scouting practices at SD Negeri 02 and 04 Buay Pematang Ribu Ranau Tengah, OKU Selatan. Researchers were reluctant to gather data through evaluation, interviews, questionnaires and documentary documentation research to assess the introduction of compulsory extracurricular practices in scouting education. Data source sampling was conducted on purpose, the compilation method used was triangulation, the data interpretation was inductive/quality, and the findings of qualitative testing stressed context rather than generalization [8]. The study cycle was one month, beginning in November and ending in December 2020. As a research study, 39 respondents (School Administrators, Classroom Teachers/Field Teachers and Scout Coaches) come from SD Negeri 02 as many as 23 respondents and 13 from SD Negeri 04 Buay Pematang Ribu Ranau Tengah. Respondents include school principals, teachers and other curriculum support staff. The research focuses on paper preparation practices (programs), on executors.

\section{RESULTS AND DISCUSSION}

Research was performed at SD Negeri 02 located on Jalan Akmal Kelurahan Simpang Sender, Buay Pematang Ribu Ranau Tengah District, Ogan Komering Ulu Selatan Regency and SD Negeri 04 located on Jalan Raya Ranau, Sukabumi Village, Buay Pematang RIbu Ranau Tengah District, Ogan Komering Ulu Selatan Regency. That school has stated that one of its vision and goal is to improve courses, talents and extracurricular activities.

On the basis of the study carried out, either by evaluation, interviews and the findings of the documentation, it can be inferred that the implementation 
is being carried out. Any real and conceptual field data are needed for this study. In comparison, the qualitative approach is more adaptive and can be tailored to significantly improve the mutual effect on the importance trends encountered and the shifting circumstances during the analysis [9]. Permendikbud Number 63 of 2014, introduced by SD Negeri 02 and SD Negeri 04 Buay Peatang Ribu Ranau Tengah, Ogan Komering Ulu (OKU) South District, has only carried out routine model operations, although block model and enhancements have not been optimally implemented. This is caused by a number of obstacles. The most critical factor is the integrity as principal, subject classroom, scout coaches and other supportive personnel who do not have the scouting skills needed at least to have a scouting orientation certificate or at least a Scout Basic Advanced Course (KMD) certificate. In addition, myths still lead to challenges to the introduction of compulsory scouting of extracurricular school programs. Misperceptions include: First, it is believed that it is incorrect if a school has adopted one of the activity models between block, update, and normal, it is perceived to have implemented Compulsory Extracurricular Scouting Education. The fact is, schools are applying all three versions. Second, there is a misunderstanding that the scout coach becomes the technical person in charge of carrying out compulsory extracurricular tasks, both the block model, the actualization model and the normal school model, such that the class teacher leaves it all to the coach concerned. The reality is that the teacher in the classroom is responsible for the technical execution of the compulsory block model and for the implementation of extracurricular activities. In the meantime, the Scout Coach is primarily responsible for the introduction of daily scouting education. The student grades are also the responsibility of the class teacher. Third, there is a misunderstanding that Permendikbud No. 63 of 2014 has not technically governed the introduction of Compulsory Extracurricular Scouting Education in Schools. The reality is that the implementation of the Scouting Compulsory Extracurricular Activities has been theoretically governed by three models, namely the block model, the update model and the standard model.

The introduction of Scouting Education Compulsory Extracurricular Activities in Schools is not straightforward, although it has been stated in the 2013 curriculum, Permendikbud No. 63 of 2014 has been published and a guidebook published by the Director of Primary School Growth in June 2018 has been published, but in fact it is not and can be revised immediately in the Front Cluster or in the Education Cluster. This is closely connected to the managerial capability and skill of human resources as managers. The potential of human capital, not only of those in the recruitment unit, but also of those in the education unit, must be involved in a dynamic way. Human Resource Skills Engagement, referred to as Handling Capabilities and Competencies. Among other aspects, the participation of the Quartir Scout Movement, the National Quartir, the Regional Quartir, the Quartir Division, the Quartir Subdistrict to Gugus Depan and the
Saka Work Unit (SAKA) was not optimum. The position of the National Office for Education and Culture is also not yet optimum. Thus, Permendikbud No. 63 of 2014 was not socialized to the full, both in the Quartir Scout Movement and in the National Education and Culture Office, which is the policy chief.

Solutions that can be made to address challenges include: First, the principal (Ka Mabigus), teachers and scout coaches can conduct a Front Cluster Conference (Mugus) every 3 (three) years in an attempt to plan a curriculum that is compatible with the criteria of K-13, with a pattern of coordinated growth between school principals, subject teachers/teachers and scout coaches. Teachers should also connect, link and combine subjects/themes with the Scouting Education menu as a compulsory extracurricular activity. In its execution, the teacher has a dual role as an educator/teacher in the classroom and as an EWPK coach on a block model and an upgrade model [4]. Second, it sets up resources for school principals, subject teachers/teachers and scout mentors to develop their skills in scouting instruction, both through the District Education and Culture Office and the Quartir Scout Movement. Third, hold meetings and organize projects together between school principals, subject teachers/teachers and scout coaches to introduce compulsory scouting of extracurricular education events in classrooms.

According to Moleong [9], in-depth interviews are a process of digging deep, open and free knowledge about issues and the focus of study aimed at the research centre. In this case, an in-depth questioning approach is used for a list of questions that have been prepared in advance. The unique aspect of in-depth interviews is their presence in the life of the respondent/informant.

\section{CONCLUSION}

Based on the results of interviews, observations and documentation were concluded: 1) there was no preparation of the curriculum and the completion of the managerial completeness of the front party that kept their place in the classroom. The Front Cluster Deliberation (Mugus) has never been performed, while the Front Gugus Deliberation must be held every 3 (three) years (Scout Movement ART Article 45(5) and ART Article $105)$; 2) they do not have the skills needed for school principals, subject teachers/teachers and scout coaches who have at least met the Scouting Orientation or have an Advanced Basic Credential (have taken an advanced Basic Course), and 3) they do not yet have the same interpretation of the compulsory extracurricular activities of school scouting between principals, subject teachers/teachers and scout coaches, so that each has its own view of the application of scouting education in schools. 


\section{AUTHORS' CONTRIBUTION}

Hamida: designed and performed experiments and analysed data.

\section{ACKNOWLEDGMENTS}

Our deepest gratitude goes to SD Negeri 04 Buay Pematang Ribu Ranau Tengah OKU Selatan Regency, Chancellor of Palembang PGRI University, Director of the Postgraduate Program of PGRI Palembang University and the Education Management Study Program of PGRI Palembang University, who have supported us in doing this extraordinary thing. This project is funded independently. We also want to thank our Education Management friends who helped us a lot in a short time frame to complete this project.

\section{REFERENCES}

[1] Rusman. (2015). Pembelajaran Tematik Terpadu Teori, Praktik dan Penilaian [Integrated Thematic Learning Theory, Practice and Assessment]. Jakarta: Rajawali Pers.

[2] Mulyasa, E. (2009). [Menjadi Guru Profesional [Become a Professional Teacher]. Bandung: PT Remaja Rosdakarya.

[3] Hanim, H., \& Rahmadoni, J. (2020). Determination of Lecturer Reception Using Analytical Hierarchy Process (AHP). Journal of Applied Engineering and Technological Science (JAETS), 1 (2), 136-141.

[4] Kepmendikbud. (2018). Panduan Ekstrakurikuler Wajib Pendidikan Kepramukaan di Sekolah Dasar [Scouting Education Compulsory Extracurricular Guide in Elementary Schools]. Jakarta: Direktorat Pembinaan Sekolah Dasar dan Menengah.

[5] Asvio, N., Yamin, M., \& Risnita. (2019). Influence of Leadership Style, Emotional Intelligence and Job Satisfaction toward Organizational Commitment (Survey at SMA Muhammadiyah South Sumatera). International Journal of Scientific \& Technology Research 8 (8).

[6] Agustina, M., Kristiawan, M., \& Tobari. (2021). The Influence of Principal's Leadership and School's Climate on The Work Productivity of Vocational Pharmacy Teachers in Indonesia. International Journal of Educational Review 3(1), 63-76.

[7] Sukmadinata, N. S. (2013). Metode Penelitian Pendidikan [Educational Research Methods]. Bandung: Remaja Rosdakarya.

[8] Sugiyono. (2009). Metode Penelitian Kuantitatif, Kualitatif dan R\&D [Quantitative Research Methods, Qualitative and $R \&$ D]. Bandung: Alfabeta.
[9] Moleong, L. J. (2005). Metodologi Penelitian Kualitatif [Qualitative Research Methodology]. Bandung: Remaja Rosdakarya

[11] Alias, N., Siraj, S., Daud, M. K. A. Md. \& Hussin, Z. (2013). Effectiveness of Facebook Based Learning to Enhance Creativity Among Islamic Studies Students by Employing Isman Instructional Design Model. "TOJET: The Turkish Online Journal of Educational Technology. January 2013, volume 12 Issue 1"

[12] Andoh, C. B. (2012). Factors Influencing Teachers' Adoption and Integration of Information and Communication Technology into Teaching: A Review of the Literature. "International Journal of Education and Development using Information and Communication Technology (IJEDICT), 2012, Vol. 8, Issue 1, pp. 136-155".

[13] Kristiawan, M. (2014). A Model for Upgrading Teachers Competence on Operating Computer as Assistant of Instruction. Global Journal of HumanSocial Science Research.

[14] Risdianto, E. Darmawan, A., Kristiawan, M., Wachidi., \& Riyanto. (2020). Rasch Model Analysis on the Feasibility Test of Basic Physics II Practical Guide using Augmented Reality. ARPN Journal of Engineering and Applied Sciences, 15(4): 482-490

[15] Maulina, U., Hikmah, S., \& Pahamzah, J. (2019). Attractive Learning Media to Cope with Students Speaking Skills in the Industry 4.0 Using Sparkol Videoscribe. Online Submission, 2(5), 132-140.

[16] Rahmatika, D. F., \& Ratnasari, N. (2018). Media Pembelajaran Matematika Bilingual Berbasis Sparkol Videoscribe [Bilingual Mathematics Learning Media Based on Videoscribe Sparkol]. Desimal: Jurnal Matematika, 1(3), 385393.

[17] Azizah, A. N. (2018). Pengembangan media pembelajaran sparkol videoscribe dalam meningkatkan minat belajar siswa pada mata pelajaran ekonomi materi perdagangan internasional di sma batik 2 surakarta [The development of sparkol videoscribe learning media in increasing students' interest in learning in economic subjects on international trade material at SMA Batik 2, Surakarta] (Doctoral dissertation, Universitas Muhammadiyah Surakarta).

18] Sudrajad, F. B., \& Hardinto, P. (2018). The Application Teams Games Tournaments and Media Learning Sparkol Video Scribe to Increase Motivation and Study Results. Classroom Action Research Journal (CARJO), 1(3), 125-132.

[19] Wulandari, D. A. (2016). Pengembangan Media Pembelajaran Menggunakan Sparkol Videoscribe dalam Meningkatkan Minat Belajar Siswa pada Mata Pelajaran IPA Materi Cahaya Kelas VIII di 
SMP Negeri 01 Kerjo Tahun Ajaran 2015/2016 [Learning Media Development Using Sparkol Videoscribe in Increasing Student Learning Interest in Science Subjects in Class VIII Light Material at SMP Negeri 01 Kerjo Academic Year 2015/2016] (Doctoral dissertation, Universitas Negeri Semarang).

[20] Maseleno, A., Ayshwary, B., Ivanova, T. N., Hashim, W., Nguyen, P. T., Shankar, K., Kristiawan, M., Huda, M. (2019). General Theoretical and Philosophical Aspects of Modern Education. Aspectos Teóricos y Filosóficos Generales de la Educación Moderna. Revista San Gregorio 2019, No. 32 Special Issues August. 